\title{
DIATEXITIC GNEISSES OF THE ANDRELÂNDIA GROUR SOUTHERN MINAS GERAIS, BRAZIL: GEOLOGICAL AND GEOCHEMICAL CONSTRAINTS
}

\author{
MARIA DO CARMO BUSTAMANTE JUNHO AND JULIO CEZAR MENDES
}

\begin{abstract}
The basal unit of the Andrelândia Group underwent barrovian metamorphism that formed stromatic biotite metatexitic gneiss grading to (garnet)-biotite-muscovite granitic diatexitic leucogneiss. The anatectic trend culminated with the formation of late- to post-tectonic (garnet)-(tourmaline)-biotite-muscovite intrusive leucogranite. The diatexites are hololeucocratic to leucocratic rocks and vary from syenogranite to granodiorite with biotite, muscovite, epidote, allanite, zircon, apatite, sphene and rare monazite and garnet. The geochemical behavior points towards a peraluminous restrict calc-alkalic sequence $\left(69 \%\right.$ to $\left.75 \% \mathrm{SiO}_{2}\right)$, with discrete major and some trace elements content variations. The observed $\mathrm{Ba}, \mathrm{Sr}, \mathrm{Y}, \mathrm{Zr}$, and mainly REE-contents oscillations define three different groups. The accessory mineralogy of the diatexites is responsible for the discrimination of these groups.

Keywords: migmatites, geochemistry, Andrelândia Group
\end{abstract}

\section{INTRODUCTION}

This paper presents geological and geochemical data of migmatites from the Andrelândia Group, Ribeira Belt, south of Minas Gerais. A new mapped area (Pouso Alto IBGE chart, 1:50.000) (Junho \& Monteiro, submitted) is added to the previous Alagoa and Liberdade maps of Silva et al. (1992), Junho (1995) and Almeida (1996). New geochemical data of diatexitic leucogneisses from Pouso Alto region are studied together with the migmatites from the Liberdade region.
GEOLOGICAL SETTING In southern Minas Gerais, the basal unit of the Andrelândia Group (Fig. 1) consists of stromatic biotite gneiss metatexites grading to (garnet)-biotite-muscovite granitic leucogneiss showing several diatexitic structures. These rocks are related to the Ribeira Mobile Belt and result from anatectic events that occurred in metasedimentary rocks of the lower sequence of the Andrelândia Depositional Cycle, ADC, of Ribeiro et al. (1995), (Junho 1995).

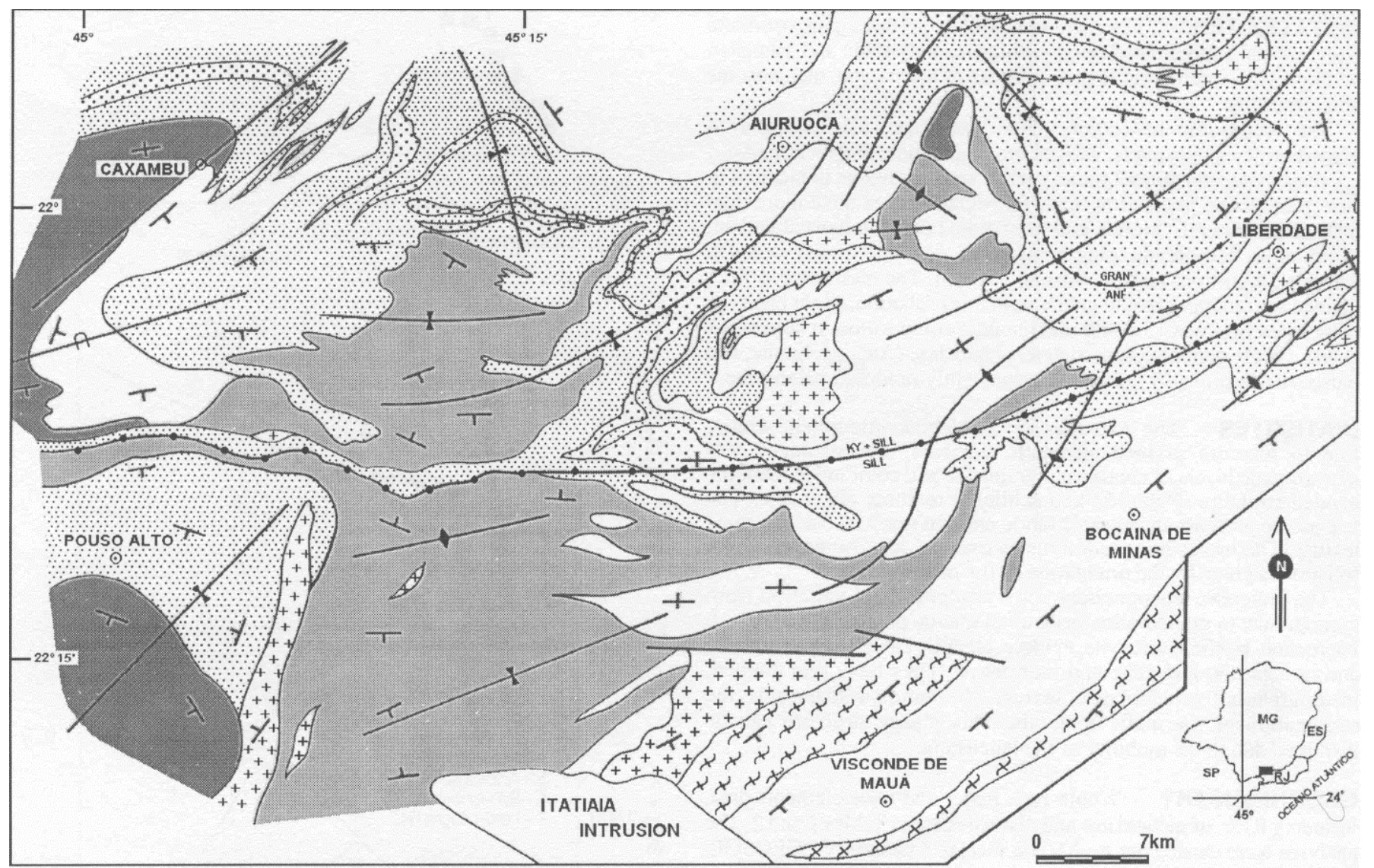

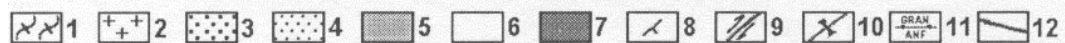

Figure 1 - Simplified geological map of the Liberdade and Pouso Alto region, southern Minas Gerais (modified from Bittar 1989, Silva et al. 1992, Junho 1995, Junho \& Monteiro 1999). Legend: (1) Hornblende porphyritic I-type granite (2) (Garnet)-(tourmaline)-biotite-muscovite late to post-tectonic S-type leucogranite (3) Kyanite/sillimanite-garnet-biotite fine-grained tonalitic gneiss (4) Kyanite/sillimanite-garnet-biotite-muscovite schist, quartz schist, feldspathic quartzite, lenses ofgondite and calcsilicate rocks, kyanite-garnet-Kfeldspar leucogneiss and kyanite-garnet-quartz-mica schist (5) (Garnet)-biotitemuscovite diatexitic leucogneiss (6) Biotite metatexitic stromatic gneiss (7) (Garnet)-(hornblende)-biotite gneiss near Caxambu and Pouso Alto (probable basement) and biotite orthogneiss near Aiuruoca (basement from Ribeiro et al. 1995) (8) D2 foliation (9) D2 shear zone (10) D3 axial trace (11) Isograds: kyanite + sillimanite / sillimanite (Silva et al. 1992) and granulite / amphibolite fades (Ribeiro et al. 1995) (12) Normal faults. 
Two deformation phases are recognized in the region (Dn and Dn+1), correlated to D2 and D3 of Ribeiro et al (1995). The earliest formed the main foliation and tight folds that repeat and thicken the units. The last (D3) deformed the previous structures resulting in open folds with steep axial surfaces and SW plunging axes. A D3 shear zone, named Caxambu, occurs in the northwest portion of the area (Bittar 1989). In the northeast, D3 formed a dome-and-basin fold pattern. Towards the south and southeast, the deformation becomes stronger and locally transposes the D2 foliation.

Rocks of region underwent syn-D2 barrovian metamorphism, with increasing temperatures and medium pressure, of upper amphibolite facies. Two distinct areas, near Pouso Alto and Liberdade, expose granulites (kyanite - garnet leucogneiss and kyanite - garnet - mica schist), interpreted by Ribeiro et al. (1995) as a product of highpressure metamorphism related to the Brasilia Belt. (Garnet) (hornblende) - biotite gneiss occurs in the west part of the area, overlying metasedimentary rocks, probably by thrust faults. Near Caxambu, Bittar (1989) interpreted a similar lithotype as basement.

The syn-D2 barrovian metamorphism culminated with the formation of migmatites and granites in the basal feldspathic metasedimentary rocks of the Andrelândia Group. The migmatites can be divided into two gradational domains: stromatic biotite gneiss with metatexitic textures and a (garnet) - muscovite - biotite leucogneiss with diatexitic textures. The diatexitic leucogneiss has concordant lenses of post-D2 (garnet) - (tourmaline) - biotite - muscovite fine grained equigranular leucogranite, which is also intrusive as small dykes and sills.

METATEXITES The metatexites have predominant stromatic structure and subordinated porphyroblastic, dictyonitic and schoellen textures, with centimetric to metric layers of leucosome, melanosome and mesosome.

The leucosome has color index less than $15 \%$, tonalitic to granodioritic compositions, with quartz, microcline, plagioclase $\left(\mathrm{An}_{23}\right.$ 29), muscovite, and minoi uiotite, garnet, and tourmaline in medium to fine-grained and pegmatitic textures. Melanosomes have more than $30 \%$ mafic minerals, biotite, and muscovite being the most abundant Sillimanite, hornblende, plagioclase $\left(\mathrm{An}_{26-33}\right)$, and quartz occur in variable proportions and K-feldspar is absent. The mesosome is finegrained equigranular biotite gneiss with mica foliation, slight banding, color index between $15-30 \%$ and tonalitic composition. It consists of quartz, poorly geminated microcline, plagioclase (An ${ }_{18-34}$ ), biotite, and + muscovite. It probably corresponds to slightly modified paleosome.

DIATEXITES The diatexites are hololeucocratic to leucocratic, fine to medium grained stromatic gneisses. Leucosomatic and mesosomatic layers of contrasting grain-size and color index mark the banded structure. Nebulitic and schlieren textures also occur. The leucosome presents an isotropic fabric and can reach a coarse-grained texture. The mesosome predominates over the leucosome. Its slight foliation is given by the orientation of the micas.

The diatexitic leucogneisses show compositional variation from syenogranite to granodiorite made up of quartz, plagioclase $\left(\mathrm{An}_{22-31}\right)$, microcline, biotite, muscovite, epidote, allanite, zircon, apatite, sphene and rare garnet, monazite and tourmaline. They have fine grained, inequigranular, lepidoblastic texture. A common feature is the aggregation of the mafic minerals. This planar structure can be disrupted due to the mobility of the leucosome.

GEOCHEMISTRY Whole-rock major and trace elements data, including REE, of metatexites and diatexites are in Tables 1 and 2. The analyses were carried out by XRF at Geolab Laboratory - GEOSOL, Belo Horizonte, Brazil.

The geochemistry of the migmatites points towards a peraluminous calc-alkalic sequence $(69 \% \text { to } 75 \% \mathrm{SiO})_{2}$, with discrete variation of the major and some trace elements content."The diagrams of figures $2 \mathrm{a}$ and $2 \mathrm{~b}$ show a clear migmatization trend from the metatexites to the diatexites. In the Shand diagram, most of the samples plot in the peraluminous field, as previously reported by Junho (1995) for these rocks in the neighboring Visconde de Maua region. Such behavior and the presence of the normative corundum indicate a metasedimentary source. The AFM diagram (Fig. 2b) highlights the greater iron contents of the metatexites and the alkalic enrichment of the most evolved diatexites. In the R1-R2 diagram (Fig; 2c), the diatexites cluster in the syn-collision field. This agrees with the observed field relations and the evolution of the Andrelândia Depositional Cycle (ADC from Ribeiro et al. 1995).

In the variation diagrams (Fig. 3), $\mathrm{Fe}, \mathrm{O}_{3} \mathrm{t}$ was chosen as the differentiation index due to its large range. $\mathrm{TiO}_{2} \mathrm{P}_{2} \mathrm{O}_{5}$ and $\mathrm{MgO}$ show a straight correlation with $\mathrm{Fe}_{2} \mathrm{O}_{3} \mathrm{t}$, enhancing the migmatitic trend. In the $\mathrm{Nb}, \mathrm{Rb}, \mathrm{P}$ and $\mathrm{Mg}$ diagrams it can be observed an inflexion in the trend around $2.5 \% \mathrm{Fe}_{2} \mathrm{O}_{3}$ t. Different melting degrees of some minerals, such as apatite, biotite, and K-feldspar, during the anatectic process could explain this change (Cox et al. 1983, Rollinson 1993). In addition, an irregular supply of water will affect the melting of the source rock and consequently the behavior of these elements (Ashworth 1985, Watt \& Harley 1993).
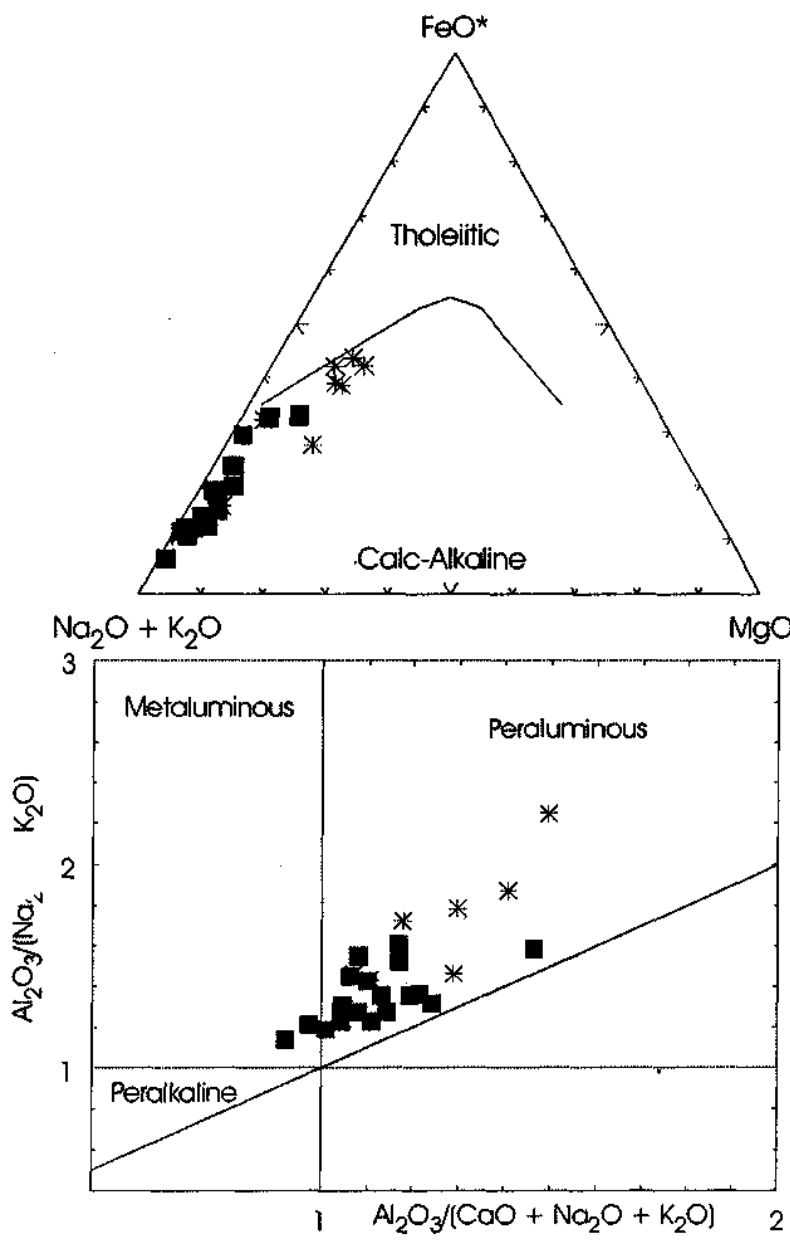

(B)

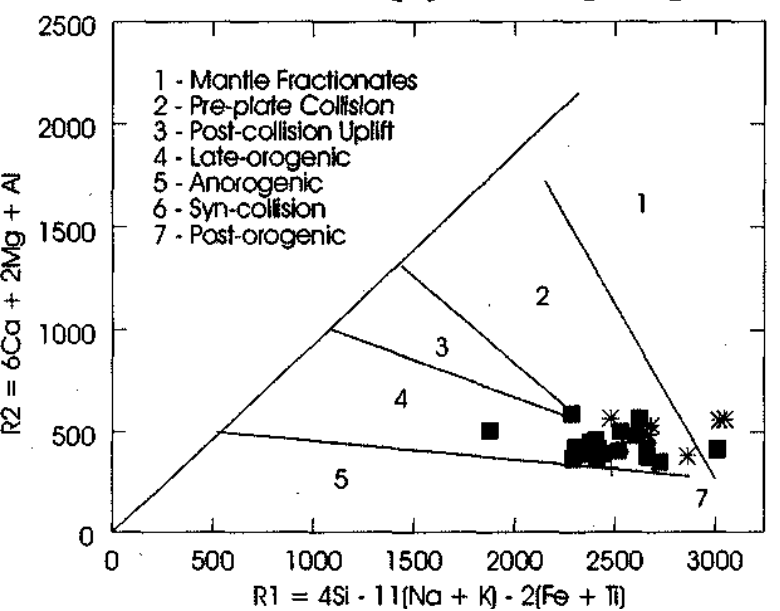

(C)

Figure 2 - (a) AFM diagram; (b) $\mathrm{Al} 2 \mathrm{O} 3 /\left(\mathrm{Na}_{2} \mathrm{O}+\mathrm{K}_{2} \mathrm{O}\right) \times \mathrm{Al}_{2} \mathrm{O}_{3} /\left(\mathrm{CaO}+\mathrm{Na}_{2} \mathrm{O}\right.$ $+\mathrm{K}_{2} \mathrm{O}$ ) diagram; (c) $\mathrm{R} 1 \times R 2$ diagram for the diatexites (filled square) and metatexites (asterisk) from Andrelândia Group, southern Minus Gerais. 


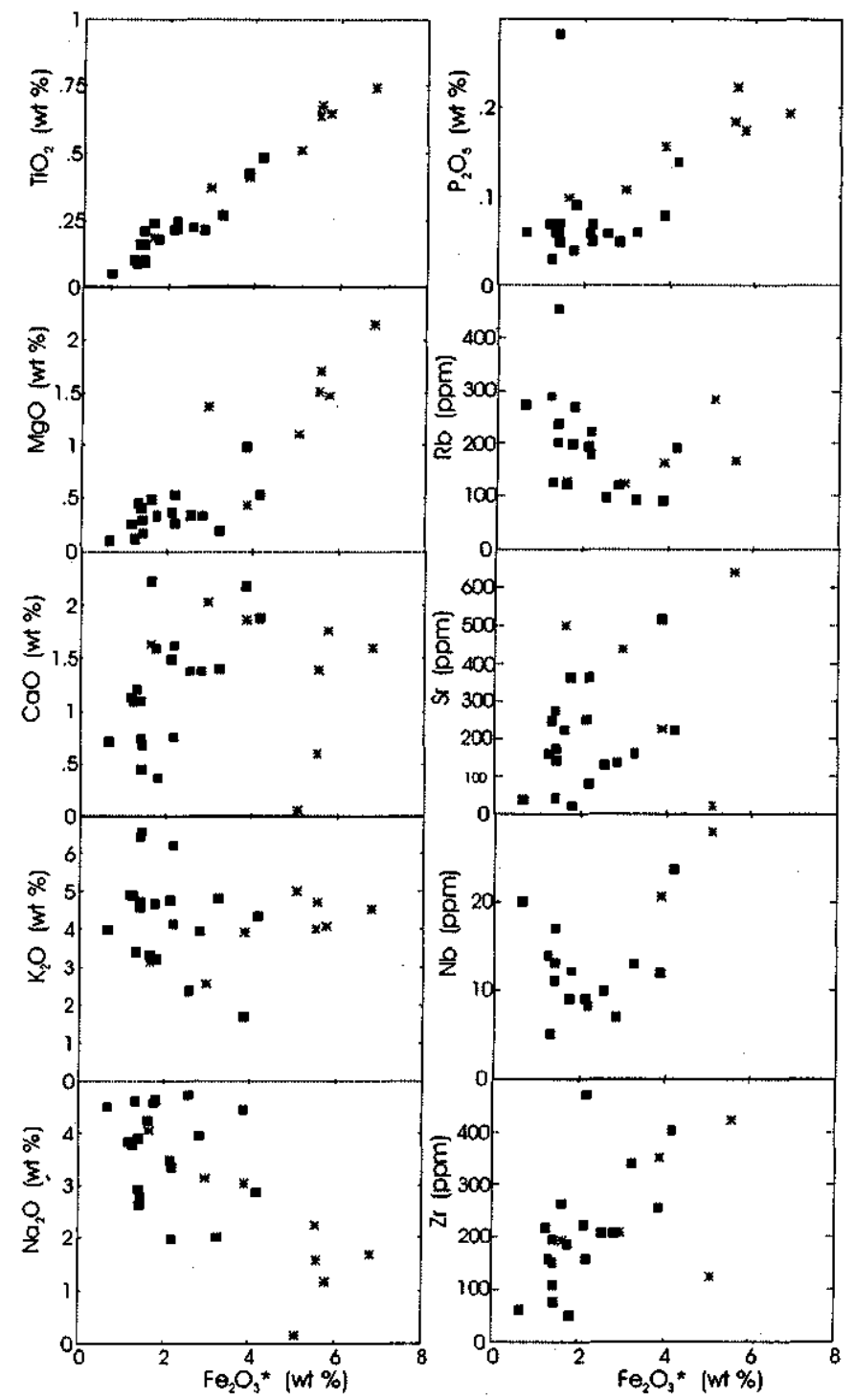

Figure 3 -Variation diagrams for the diatexites (filled square) and metatexites (asterisk) from Andrelândia Group, southern Minas Gerais.

Table 1 - Chemical composition of metatexites from Andrelândia Group, southern Minas Gerais. Samples from Visconde de Maud - Liberdade region.

\begin{tabular}{|l|cccccccccc|}
\hline & $\mathrm{R}-$ & $\mathrm{R}-$ & $\mathrm{R}-$ & $\mathrm{M} 39$ & $\mathrm{M}-$ & $\mathrm{R}-$ & $\mathrm{R}-75$ & $\mathrm{R}-$ & $\mathrm{R}-$ & $\mathrm{R}-$ \\
& 311 & 316 & 315 & $\mathrm{~A}$ & $11 \mathrm{C}$ & 310 & & 331 & 317 & 174 \\
\hline $\mathrm{SiO}_{2}$ & 66 & 68.37 & 69.05 & 71 & 71.8 & 72.2 & 72.67 & 72.73 & 73.2 & 73.8 \\
$\mathrm{TiO}_{2}$ & 0.77 & 0.7 & 0.67 & 0.51 & 0.42 & 0.66 & 0.1 & 0.25 & 0.38 & 0.19 \\
$\mathrm{Al}_{2} \mathrm{O}_{3}$ & 14.2 & 14.84 & 14.69 & 14.5 & 13.8 & 12.1 & 14.75 & 14.39 & 13.9 & 14.6 \\
$\mathrm{Fe}_{2} \mathrm{O}_{3}$ & 7.05 & 5.76 & 5.96 & 5.07 & 3.97 & 5.71 & 1.19 & 2.21 & 3.02 & 1.66 \\
$\mathrm{MnO}$ & 0.37 & 0.16 & 0.3 & 0.09 & 0.01 & 0.14 & 0.23 & 0.15 & 0.06 & 0.12 \\
$\mathrm{MgO}$ & 2.22 & 1.76 & 1.52 & 1.1 & 0.44 & 1.56 & 0.25 & 0.53 & 1.39 & 0.49 \\
$\mathrm{CaO}$ & 1.65 & 1.44 & 1.82 & 0.06 & 1.9 & 0.62 & 1.13 & 1.64 & 2.06 & 1.65 \\
$\mathrm{Na}_{2} \mathrm{O}$ & 1.75 & 1.62 & 1.2 & 0.15 & 3.1 & 2.3 & 3.83 & 3.39 & 3.19 & 4.1 \\
$\mathrm{~K}_{2} \mathrm{O}$ & 4.7 & 4.87 & 4.21 & 5 & 4 & 4.15 & 4.89 & 4.18 & 2.6 & 3.2 \\
$\mathrm{P}_{2} \mathrm{O}_{5}$ & 0.2 & 0.23 & 0.18 & 0 & 0.16 & 0.19 & 0.07 & 0.07 & 0.11 & 0.1 \\
$\mathrm{LOI}$ & 1.35 & 0.12 & 1.19 & 2.35 & 0.47 & 0.84 & 0.72 & 0.54 & 0.78 & 0.76 \\
$\mathrm{Total}$ & 100.2 & 99.87 & 100.8 & 99.83 & 100.1 & 100.4 & 99.83 & 100.0 & 100.7 & 100.6 \\
$\mathrm{Rb}$ & n.a. & 172 & n.a. & 283 & 166 & n.a. & n.a. & 224 & 126 & 129 \\
$\mathrm{Ba}$ & n.a. & 1395 & n.a. & 395 & 1264 & n.a. & n.a. & 1213 & 1195 & 1182 \\
$\mathrm{Sr}$ & n.a. & 660 & n.a. & 21 & 229 & n.a. & n.a. & 366 & 445 & 504 \\
$\mathrm{Zr}$ & n.a. & 437 & n.a. & 123 & 358 & n.a. & n.a. & 475 & 211 & 475 \\
\hline
\end{tabular}

n.a. $=$ not analysed

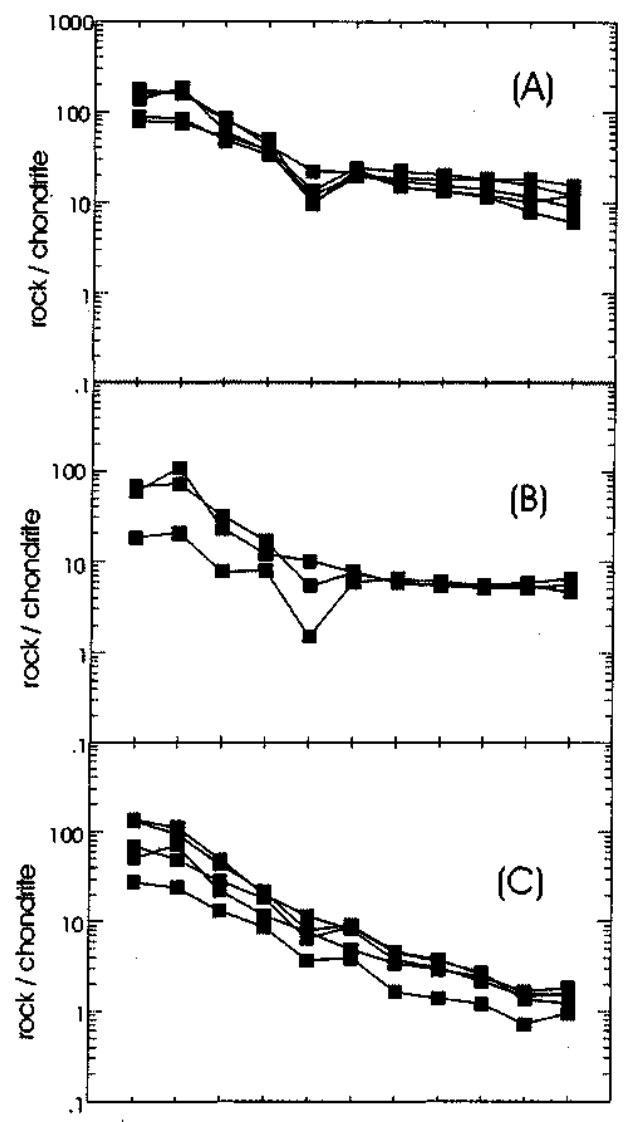

La Ce Nd SmEu GdDy Ho Er Yb Lu

Figure 4 - Chondrite normalized (Boynton 1984) REE diagrams of the diatexites from Andrelândia Group, southern Minas Gerais.

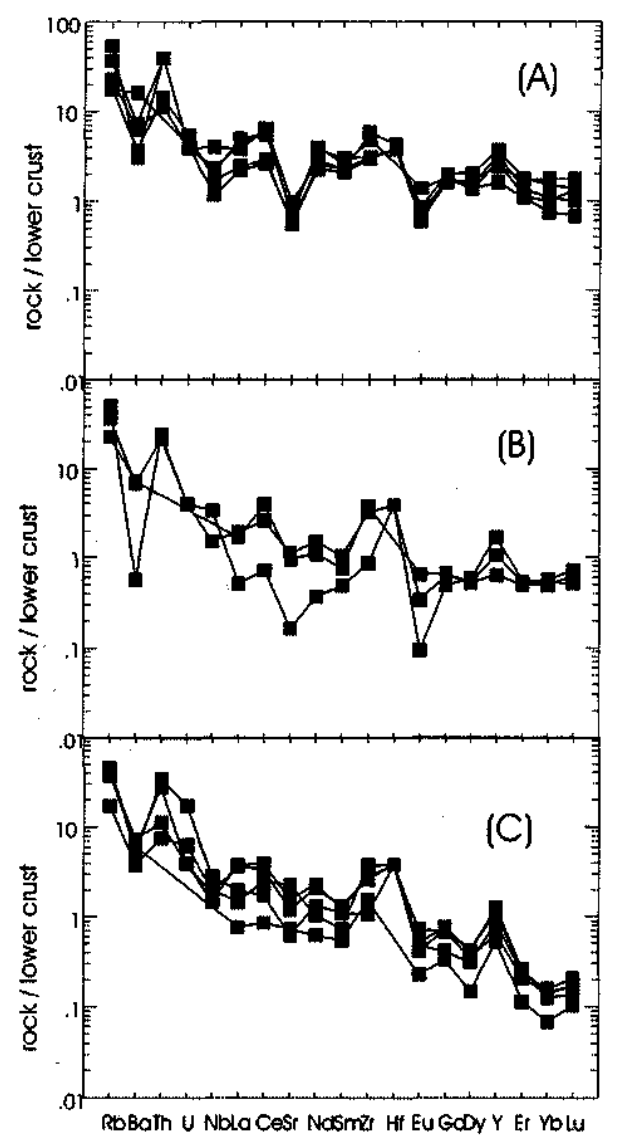

Figure 5 - Multi-elemental normalized (Taylor \& McLennan 1985) diagrams of the diatexites from Andrelândia Group, southern Minas Gerais. 
Table 2 - Chemical composition of diatexites from Andrelândia Group, southern Minas Gerais. Samples named L are from Pouso Alto region.

\begin{tabular}{|c|c|c|c|c|c|c|c|c|c|c|c|c|c|c|c|c|}
\hline & AL-116 & $\mathrm{L}-227 \mathrm{~B}$ & L-131 & L-109 & M139 & $\mathrm{M}-5 \overline{\mathrm{B}}$ & $\mathrm{L}-99 \mathrm{~B}$ & $\mathrm{M}-7 \mathrm{~B}$ & $\mathrm{~L}-49$ & M-29B & L-230 & M-9 & $\mathrm{L}-220$ & L-52D & $\mathrm{L}-127$ & $\mathrm{~L}-220 \mathrm{~A}$ \\
\hline $\mathrm{SiO}_{2}$ & 68.9 & 69.9 . & 70.6 & $\because 71$ & 71.8 & 72.5 & 72.5 & 72.7 & 73 & 73.7 & 73.8 & 74.1 & 74.3 & 74.5 & 74.6 & 75 \\
\hline $\mathrm{TiO}_{2}$ & 0.24 & 0.18 & 0.49 & 0.43 & 0.1 & 0.21 & 0.22 & 0.16 & 0.09 & 0 & 0.16 & 0.27 & 0.22 & 0.05 & 0.09 & 0.23 \\
\hline $\mathrm{Al}_{2} \mathrm{O}_{3}$ & 16.9 & 16.3 & 13.8 & 14.3 & 15.2 & 15.6 & 14.3 & 15.2 & 14.4 & 14.5 & 14 & 12.9 & 12.4 & 14.9 & 13.7 & 12.7 \\
\hline $\mathrm{Fe}_{2} \mathrm{O}_{3}$ & 1.61 & 1.77 & 4.23 & 3.92 & 1.41 & 1.4 & 2.14 & 1.32 & 1.44 & 1.79 & 1.41 & 3.24 & 2.87 & 0.66 & 1.26 & 2.59 \\
\hline $\mathrm{MnO}$ & 0.05 & 0.02 & 0.05 & 0.08 & 0.05 & 0 & 0.03 & 0 & 0.01 & 0.04 & 0.01 & 0.03 & 0.06 & 0.06 & 0.02 & 0.05 \\
\hline $\mathrm{MgO}$ & 0.48 & 0.34 & 0.53 & 0.99 & 0.29 & 0 & 0.37 & 0.45 & 0.17 & 0 & 0.4 & 0.19 & 0.33 & 0.1 & 0.12 & 0.34 \\
\hline $\mathrm{CaO}$ & 2.2 & 1.6 & 1.9 & 2.2 & 0.73 & 0.44 & 1.5 & 1.2 & 0.68 & 0.36 & 1.1 & 1.4 & 1.4 & 0.71 & 1.1 & 1.4 \\
\hline $\mathrm{Na}_{2} \mathrm{O}$ & 4.2 & 4.6 & 2.9 & 4.5 & 2.6 & 2.9 & 3.5 & 4.6 & 2.8 & 4.6 & 3.9 & 2 & 4 & 4.5 & 3.8 & 4.8 \\
\hline $\mathrm{K}_{2} \mathrm{O}$ & 3.3 & 4.7 & 4.4 & 1.7 & 6.4 & 4.7 & 4.8 & 3.4 & 6.6 & 3.2 & 4.6 & 4.8 & 4 & 4 & 4.9 & 2.4 \\
\hline $\mathrm{P}_{2} \mathrm{O}_{5}$ & 0 & 0.04 & 0.14 & 0.08 & 0.07 & .0 .28 & 0.06 & 0.06 & 0.05 & 0.09 & 0.06 & 0.06 & 0.05 & 0.06 & 0.03 & 0.06 \\
\hline LOr & 1.36 & 0.37 & 0.64 & 0.57 & 1.17 & 1.58 & 0.36 & 0.85 & 0.58 & 1.06 & 0.32 & 0.8 & 0.18 & 0.54 & 0.22 & 0.26 \\
\hline Total & 99.24 & 99.82 & 99.68 & 99.77 & 99.82 & 100 & 99.78 & 99.94 & 99.82 & 99.34 & 99.76 & 99.79 & 100.3 & 100.1 & 99.84 & 100.3 \\
\hline $\mathrm{Rb}$ & 120 & 198 & 193 & 91 & 199 & 452 & 194 & 126 & 238 & 266 & 235 & 92 & 121 & 271 & 290 & 98 \\
\hline $\mathrm{Ba}$ & 1075 & 1095 & 1082 & 568 & 909 & 133 & 1042 & 958 & 764 & 61 & 921 & 2418 & 931 & 85 & 462 & 565 \\
\hline $\mathrm{Sr}$ & 220 & 365 & 224 & 521 & 21 & 42 & 253 & 248 & 143 & 20 & 274 & 161 & 137 & 38 & 160 & 131 \\
\hline $\mathrm{Nb}$ & n.a. & 9 & 24 & 12 & $\because$ & 13 & 9 & 5 & 17 & 12 & 11 & 13 & 7 & 20 & 14 & 10 \\
\hline $\mathrm{Zr}$ & 260 & 185 & 407 & 258 & 107 & 148 & 222 & 155 & 75 & 49 & 193 & 339 & 208 & 60 & 216 & 209 \\
\hline Y & 12 & 12 & 62 & 16 & 10 & n.a. & 20 & n.a. & 24 & 10 & 21 & 31 & 70 & 32 & 52 & 46 \\
\hline $\mathrm{La}$ & 18.39 & $41: 91$ & 42.1 & 15.92 & 8.41 & 23.12 & 20.76 & 31.09 & 21.49 & 4.7 & 40.59 & 54.37 & 24.39 & 5.63 & 48.13 & 26.94 \\
\hline $\mathrm{Ce}$ & 88.41 & 90.28 & 146.4 & 57.24 & 19.48 & 59.97 & 59.01 & 55.85 & 39.62 & 8.72 & 76.63 & 127.2 & 60.91 & 16.43 & 130.6 & 67 \\
\hline Nd & 13.75 & 29.27 & 36.72 & 13.17 & 7.99 & 28.49 & 19.07 & 20.77 & 17.11 & 7.66 & 26.33 & 50.65 & 31.87 & 4.68 & 48.01 & 28.94 \\
\hline $\mathrm{Sm}$ & 2.36 & 3.96 & 7.05 & 2.29 & 1.71 & 4.82 & 3.3 & 3.13 & 3.5 & 2.3 & 4.2 & 8.32 & 7.36 & 1.54 & 9.57 & 6.6 \\
\hline $\mathrm{Eu}$ & 0.75 & 0.84 & 0.75 & 0.56 & 0.27 & 0.23 & 0.4 & 0.68 & 0.48 & 0.21 & 0.59 & 1.62 & 0.99 & 0.11 & 0.71 & 0.91 \\
\hline $\mathrm{Gd}$ & 2.03 & 2.13 & 5.07 & 1.28 & 1.03 & 2.15 & 1.94 & 1.76 & 2.22 & 1.46 & 2.39 & 5.55 & 6.21 & 1.53 & 6.06 & 5.16 \\
\hline Dy & 1.88 & 1.22 & 5.63 & 1.12 & 0.54 & 0.87 & 1.93 & 0.93 & 1.47 & 2.15 & 1.5 & 4.93 & 7.26 & 2.12 & 4.94 & 6.07 \\
\hline Ho & 0.39 & 0.22 & 1.12 & 0.21 & 0.1 & 0.15 & 0.4 & 0.15 & 0.26 & 0.53 & 0.27 & 0.96 & 1.45 & 0.43 & 0.97 & 1.28 \\
\hline $\mathrm{Er}$ & 1.09 & 0.46 & 2.98 & 0.51 & 0.25 & 0.31 & 1.12 & 0.25 & 0.58 & 1.91 & 0.54 & 2.44 & 3.9 & 1.17 & 2.53 & 3.76 \\
\hline $\mathrm{Yb}$ & 1.08 & 0.31 & 2.42 & 0.35 & 0.15 & 0.25 & 1.15 & 0.17 & 0.28 & 1.89 & 0.33 & 1.67 & 3.32 & 1.23 & 2.16 & 3.87 \\
\hline Lu & 0.18 & 0.05 & 0.29 & 0.06 & 0.03 & 0.03 & 0.15 & 0.03 & 0.04 & 0.19 & 0.05 & 0.2 & 0.4 & 0.21 & 0.39 & 0.51 \\
\hline
\end{tabular}
n.a. = not analysed

The $\mathrm{CaO}, \mathrm{Na}_{2} \mathrm{O}$, and $\mathrm{Sr}$ versus $\mathrm{Fe}_{2} \mathrm{O}_{3}$ t diagrams show a high dispersion that can be related to variable melting degree of plagioclase from the metatexites (Mehnert \& Bush 1982). Junho (1995) pointed out the restrict An-content variation $\left(\mathrm{An}_{22-31}\right)$ of the metatexites and diatexites, without any An enrichment. Similarly, the dispersion of $\mathrm{K}_{2} \mathrm{O}$ must be associated to melting and crystallization of microcline and muscovite.

Trace elements, including REE, of the diatexites are presented in the Table 2. The REE patterns evidence three different groups (Fig. 4). One has the higher REE-contents, less fractionated pattern, flattening through the intermediate and heavy REE, and a conspicuous negative $\mathrm{Eu}$ anomaly (Fig. 4a). Another group is similar to the first, but it differs in the LREE fractionation and in the total REE, and one sample does not exhibit Eu anomaly (Fig. 4b). The last group is the most fractionated, has the lowest HREE and variable and small Eu anomaly (Fig. 4c). The spidergrams (Fig. 5) enhance the HREE differences among the groups. The patterns show negative $\mathrm{Ba}, \mathrm{Sr}$ and $\mathrm{Eu}$ anomalies and positive Th and $\mathrm{Y}$ anomalies in the diatexites as compared to lower crust values.

CONCLUSIONS The new presented data show a close geological, petrographic and geochemical correlation between the migmatites from Pouso Alto region and the metatexites and diatexites from Liberdade region. The diatexitic leucogneisses form a peraluminous restrict calc-alkalic trend $\left(69 \%\right.$ to $\left.75 \% \mathrm{SiO}_{2}\right)$, with normative corundum, pointing to a metasedimentary source and show an homogeneous geochemical behavior of a probable syn-collisional magmatism. In spite of the homogeneity of the diatexites, their REE and spidergrams patterns reveal the existence of three different groups. The variable occurrence of the accessory minerals is the main distinguishing feature between rocks of the three groups. The presence of these phases has a strong influence on the observed REE-contents variations (Rollinson 1993). The greater quantities of allanite/epidote, titanite, apatite, zircon, and garnet are responsible for the higher intermediate and heavy REE-contents (Schaltegger \& Krahenbuhl 1990), as shown in the figures $4 \mathrm{a}$ and $4 \mathrm{~b}$. In the most fractionated group (Fig. 4c), the rocks have less allanite, zircon, apatite, and garnet, what explains the lower quantities of intermediary and heavy REE. The different intensities of Eu anomaly are likely to be related to variations in the partial melting degree of the metasedimentary source rocks (Watt \& Harley 1993).

Acknowledgments We thank UFRJ, CNPq and FAPERJ for research grants and the anonymous reviewers for improving the manuscript. 


\section{References}

Almeida M. 1996. Geologia, Petrografia e Geoquímica do Leucogranito Capivara, Itamonte, $M G$. Depto. de Geojogia, UFRJ, Dissertacão de Mestrado, $128 \mathrm{p}$. Ashworth J, 1985. Introduction. In: Asbwort, J. R. editor, Migmatites. Blackie, Glascow, $135 \mathrm{p}$.

Bittar S. 1989, Mapeamento Geologico-Estrutural da Folha Caxambu e pane sul da Fo lha Lumindrias, Minus Gerais. Depto. de Geologia, UFRJ, Dissertas3p de Mestrado, 226 p.

Boynton W.V. 1984. Cosmochemistry of the rare earth element: meteorite studies. In: P. Henderson (ed)/tore Earth Element Geochemistry. Amsterdan, Elsevier 63-114,

Cox K.G., Bell J.D,, Pankhurst R.J. 1979. The interpretation of igneous rocks, Unwin Hyman Ltd., London. 450p.

Junho M. 1995. Leucogranites and Related Migmatites, Southern Minas Gerais and Southwestern Rio de Janeiro States, Brazil. An. Acad bras. Ci. 67(4): 497-515.

Southwestern Rio de Janeiro States, Brazil. An. Acad. bras. Cl., 67(4): 497-515,
Junho M., Monteiro M. 1999. Geologia da Folha IBGE Pouso Alto (1:50.000). Anuário do IGEO - UFRJ, Rio de Janeiro, (submitted).

Mehnert K. R., Busch W. 1982, The initial stage of migmatitie formation. N. Jh. Miner. Abh. 145 (3): $211-238$

Ribeiro A., Trouw R., Andreis R.R., Paciullo F., Valenca J. 1995. Evolução das Bacias Proterozóicas e o Termo-Tectonismo Brasiliano na Margem Sul do Craton do São Francisco. Rev. Bras. Geociências, 25(4): 235-248
Rollinson H. 1993. Using geochemical data: evaluation, presentation, interpretation Longman Group Ltd., England, $352 \mathrm{p}$.

Schaltegger U., Krahenbuhl, U. 1990. Heavy rare-earth element enrichment in granites of the Aar Massif (Central Alps, Switzerland), Chemical Geologv, 89:49-63.

Silva R, Junho M., Monsores A., Nogueira J., Alves M. 1992. Geologia do Grupo Ändrelândia na região de Carvalhos, sul de Minas Gerais. Rev. Esc. Minas Ouro Preto,46(1\&2).p. 210-212.

Taylor S., McLennan S. 1985. The continental crust: its composition and evolution. Blackwell, Oxford, $312 \mathrm{p}$

Watt G,, Harley S. 1993 Accessory phase controls on the geochemistry of crustal melts and restites produced during water undersatured partial melting. Contrib. Mineral.

Petrol., 114: 550-566.

Contribution IGC-071

Received 18 February 2000 Accepted for publication 5 April 2000 